\title{
Will e-Governance and e-Democracy Lead to e-Empowerment? Gendering the Cyber State
}

\author{
Kathleen McNutt, Simon Fraser University \\ Department of Political Science, Ph.D Candidate
}

The onslaught of information and communications technologies (ICTs), the burgeoning popularity of the Internet, and the ideology behind the new information economy has coalesced into a force that is fundamentally reshaping the contours of the Canadian political landscape. This reorganization of the state will profoundly impact women's opportunities to participate in and alter conventional notions of citizenship. The establishment of electronic or e-government and the implications behind the development of the cyberstate promise to revolutionize Canadian governance and our traditional understandings of democracy. While there is the political possibility of shaping the emerging cyberstate as a vehicle of empowerment for women and marginalized others, there is also the prospect that Internet-facilitated government will exacerbate inequalities and impair women’s citizenship status.

For the third year in a row Canada has been crowned the global frontrunner in the development and implementation of e-government. The shift from traditional roles of government to the new electronic state corresponds closely with the process of digital restructuring and the well-established governance model of neoliberalism. Feminist scholarship has produced a wealth of literature focused on the gendered implications of neoliberalism and collateral restructuring process, most of which argues that women will be disproportionately impacted by this particular mode of governing. ${ }^{1}$ The current period of digital restructuring and the emergence of the

\footnotetext{
${ }^{1}$ Most feminist scholars argue that the current reconfiguration of the Canadian polity will usher in new forms of patriarchal and capitalist control and will disproportionately affect women as the state downloads responsibility into the private sphere. The understanding that the new citizenship regime

McNutt, Kathleen. "Will e-Governance and e-Democracy Lead to e-Empowerment? Gendering the Cyber State.” Federal Governance: A Graduate Journal of Theory and Politics. 4.1 (2004).

<http://www.cnfs-rcef.net/federalgovernance/content/volume4/articles/Kathleen_McNutt.pdf>
} 
newly contrived electronic state provide feminist interests with an opportunity to negotiate women's space in the information revolution. The restructuring process signifies reorganization and change, which invites women's participation in determining what institutional outcomes and gender sensitive foci are necessary to address women's online political desires and needs. Promoting women's involvement in the digital restructuring of the state and ensuring that a gendered analysis is utilized in the project of e-government is a central concern for equality.

Substantively this paper is an inquiry into the gendered dimensions of egovernment, e-governance and e-democracy. I explore the possibility of electronic government serving as a fundamental catalyst for invoking women’s participation in political and social outcomes and examine how women are best able to negotiate space in this new state configuration. Two primary questions guide this research. First, how is the emergence of the electronic state impairing or improving women's political status? Second, what key tenets will provide the necessary impetus for women's empowerment in relation to this new state form? In order to address these questions this paper will be divided into five sections.

As this project will be focused primarily on political outcomes and the gendered implications of a cyberstate it is necessary to establish several theoretical definitions that will guide the analysis. The primary objective of this project is to determine what steps are necessary for empowering women in the emerging

must be viewed as a social construct that reflects, not only the governance mentality of neoliberalism, but also the underlying ideology of neoconservatism. Through this lens women-centered theorists are arguing that within the new citizenship regime, citizens are expected to take care of themselves and those who fail to become self-sufficient are considered problematic and deviant. However, Janine Brodie identifies a paradox of our current situation in that "[a]lthough the political economy of the new order marks an intensification of gender, restructuring discourse denies its political significance. The rhetoric around market-driven adjustment is both dehumanized and degendered. Similarly, the discourse around the deficit and erosion of the welfare state obscures the unequal gendered impacts of this so-called “belt-tightening” episode in Canadian political development. In turn, the women's movement has lost its privileged position as the representative of the collective interests of women in the welfare state. Instead, it is being recast as just another special interest group whose claims for state intervention are both self-interested and oppositional to the collective interest. See: Janine Brodie, "Restructuring and the Politics of Marginalization" in Women and Political Representation in Canada (Ottawa: University of Ottawa Press, 1998), 34. For a full discussion on this topics see: Isabella Bakker, Unpaid Work and Macroecnomics: New Discussions, New Tools for Action (Ottawa: Status of Women Canada, 1998), passim; Jane Jenson and Susan D. Philips, "Regime Shift: New Citizenship Practices in Canada” in International Journal of Canadian Studies, vol.14 (Fall 1996). 
cyberstate. Empowerment will be understood as participation in those decisionmaking processes that impacts the social, political and economic conditions of society. Women's involvement in political actions, social projects or economic activities, processes of dialogue, critical reflections and community involvement are all fundamental leveraging tools for advancing women's equality and influencing policy outcomes. To nurture and support women's participation it will be necessary to establish an enabling environment, which in the context of e-governance is characterized by state-sponsored policies and infrastructures that promote gender equality and women's empowerment. For the purposes of this project, neoliberalism will be defined as "an ideology that advocates an economic arena free of government regulation and restriction, including labour and environmental legislation, and certainly free of government action via public ownership. It advocates a retreat from the welfare state's publicly funded commitments to equality and social justice. It views citizenship as consumption and economic production” (Green: 1996, 112). Throughout this paper I will be referring to women as 'actors' as opposed to clients or users. I do this to punctuate the potential of ICTs to engage women in transformative political activities and to become self-actualizing agents within their personal lives.

Although there is an enormous cache of online lingo and technical jargon there will be certain terms employed throughout this project that deserve immediate clarity. A portal is a single website that provides access to multiple applications, information, and content. For instance, America Online serves as a massive portal for access to the Internet. The virtual women's movement is the organization of womencentered groups, collectives, and individuals online that promote gender equality through educational campaigns, discussions groups, forums, and cyber-activism. Cyber-activism "includes virtual marches (jamming communication lines by bombarded a targeted organization with emails, faxes and phone calls), bulletin boards advertising a variety of feminist political actions, feminist list-serves, and massive world wide petitions” (McNutt). 


\section{e-government \& e-governance: Digitalizing the Canadian State}

The use of digital technology to improve public access to government and promote the increased participation of individual Canadians in the decision-making process promises to revolutionize conventional political activities. The federal government's intense commitment to instituting a system of e-government has been crystallized over the past several years in numerous speeches, financial commitments and policy initiatives. $^{2}$ In the 1999 "Speech from the Throne," the federal government informed citizens that Canada would "become a model user of information technology and the Internet. By 2004, [their] goal is to be known around the world as the government most connected to its citizens, with Canadians able to access all government information and services on-line at the time and place of their choosing” (GOL). The pledge was backed with $\$ 5$ million annually in moneys earmarked for ICTs and the Government Online (GOL) project (Longford, 5). This commitment was reiterated in the 2001 "Speech from the Throne" with the statement "Canada must continue to develop and strengthen its information infrastructure...the Government will continue to work toward putting its services on-line by 2004, to better connect with citizens” $(G O L)^{3}$

The first plateau of the digitalization of Canadian government involved the creation and promotion of government websites and the organization of a system of egovernment. This stage was primarily concerned with developing a digital

\footnotetext{
${ }^{2}$ Although Ottawa officially announced plans for the e-government project in 1999, "governments in Canada have been leveraging IT [information technologies] to rationalize and restructure administrative systems and service delivery for well over a decade.” Graham Longford, Rethinking EGovernment: Dilemmas of Public Service, Citizenship and Democracy in the Digital Age. Presentation to The Workshop on Public Sector Innovation. Sponsored by The Innovation Journal (Ottawa: The University of Ottawa, Carleton University, École national d'administration publique), 2.

${ }^{3}$ Throughout the developed world the execution of the e-government project has progressed in distinct phases. Flowing from the advice of the United Nations many states are using a five step program to ensure seamless implementation. The UN identifies these stages as "Emerging: An official government online presence is established, Enhanced: Government sites increase; information becomes more dynamic. Interactive: Users can download forms, e-mail officials and interact through the web. Transactional: Users can actually pay for services and other transactions online. Seamless: Full integration of e-services across administrative boundaries.” The manifestation of e-government in Canada has closely paralleled the United Nation's five-step model; however the speed with which the implementations has progressed blurs any explicit demarcation between the specific junctures. United Nations: Division for Public Economics and Public Administration American Society for Public Administration, Benchmarking E government: A Global Perspective (May, 2002), 2.
} 
infrastructure, ensuring that sufficient expertise was available to fulfill the mandate of electronic government, and marketing the project to the general public. During this phase the government sought to enhance access to information and create a national web presence. The second plateau of the virtual state entailed a process of interaction in which individuals could join e-mail lists, use government search engines, watch web broadcasts and so forth. In this phase we see the first indication of an altered citizen-state relationship, as individual citizens are now using digital technology to interact online with government agencies. ${ }^{4}$ The next plateau of development consists of on-line transactions between the government and citizens, business interests, the third sector and a variety of other clients. In this stage we are witnessing the emerging popularity of portals, e-polling, e-surveys, and do-it-yourself services such as income tax, online forms, and employment recruitment. The final plateau of this progression of the virtual state will be the establishment of a brand new form of political organization - e-governance/networked government. What exactly this novel type of governance will mean for women and other marginalized Canadians is contestable terrain.

Governance is a fundamental aspect of both the organization of democracy and the relationship between the civic community and government officials. In order to gauge the potential for e-governance to engage women's political participation it is necessary to determine exactly what constitutes 'good governance.' Governance is the process by which political decisions are made and power is exercised through state institutions. 'Bad' governance is often associated with corruption, abuse of power, state sanctioned human rights violations and the failure to acquiesce to certain

\footnotetext{
${ }^{4}$ The Public Policy Forum, a non-profit, non-partisan organization, recently completed research on how the federal government's $G O L$ initiative was progressing and whether or not the program was facing any major barriers or inefficiencies in development. The Policy Forum criticized the project for “A) the GOL 'Vision' articulated in the 1999 and 2001 Speeches from the Throne needs to be better defined and articulated. B) Departments have no guidance on the priority that they should assign GOL in relation to other public service management reform initiatives. C) The $G O L$ vision, however defined, will not be achieved at current central funding levels. D) Departments do not have a clear sense of the overall strategy for implementing GOL.” Despite internal problems and the above mentioned challenges the project of e-government is rapidly being deployed at all levels of government and presumably the system should be running smoothly by the time the final plateau is implemented. The Public Policy Forum, The Governance of Government On-Line: A Report on Research Conducted by the Public Policy Forum for the Chief Information Officer of the Treasury Board Secretariat (Canada, March 30, 2001), 6.
} 
global standards and expectations. In contrast, 'good' governance is characterized by the rule of law, citizen participation and consultation in decision-making processes, transparency, accountability, efficiency in service delivery and integrity. ${ }^{5}$ Democratic participation is a core prerequisite for good governance. The system of e-government currently being implemented does possess, to varying degrees, each one of the characteristics that is popularly considered to constitute good governance. In theory, e-government will serve as a revolutionary new mode of statecraft, operating to increase citizen participation, renew the public service sector through the horizontal integration of online services, promote democratic empowerment and provide an enabling online environment that pursues the goals of equality, efficiency and inclusion. As Cynthia Alexander observes "the shape of governance itself is being reinvented in ways that merit ongoing attention and critical evaluation. The government of Canada is becoming a model user of new information and communication technologies” (205-206).

The digitalization of government represents a transitional moment in Canadian history. Modernizing the state through electronic service delivery will

5 The Organisation for Economic Co-operation and Development suggests that good governance, especially in relation to e-government should be based on: "Legitimacy: The credibility of governance institutions ultimately depends on their ability to deliver results that respond to the needs and expectations of their constituents. Sustainable societies must focus on citizens' needs because the authority of democratic governments depends on the consent of its citizens to be governed. $\bullet$ Rule of Law: Transparent and fairly-applied laws, regulations and codes should be enforced equally. $\bullet$ Transparency, accountability, and integrity: Transparency promotes effective governance by opening up decision-making processes to public scrutiny and enhancing the degree to which constituents can hold governance institutions to account. Effective governance requires ethical behavior and vigorous action to fight corruption. Integrity is a pre-condition for the creation of a trustworthy and effective framework of governance. Effective governance institutions are answerable to their constituencies, whether they be shareholders or citizens. Accountability entails the existence of reporting and feedback mechanisms. • Efficiency: Efficient governance institutions demonstrate good stewardship of resources by achieving concrete results with a minimum of waste, while following agreed-upon standards and procedures. Achieving efficiency requires effective and responsive policies for building and maintaining well performing and efficient institutions to deliver quality services. • Coherence: Coherence helps to ensure that the combined set of an institution's policies is serving the same goals. - Adaptability: Effective governance is not static. New risks are constantly emerging and societies need to continuously reflect on the values their governance arrangements are intended to promote and to anticipate changing needs and meet them through innovative procedures and new policies. Participation and Consultation: Participation and consultation are mechanisms for identifying and aggregating the will of constituents. Building them into the decision-making process can increase support for governance institutions and their policies. Consultation and informed participation can also help lead to policies that better address constituents' needs.” Organisation for Economic Co-operation and Development. E-government: Analysis Framework and Methodology (France: Public Management Services, 2001), 3-4. 
fundamentally alter previous understandings of Canadian democracy and by extension radically transform the current relationship between the state and the citizenry. As the digital restructuring of Canada and the new mode of governance are propelled forward, analysis focused on the gendered dimensions of the new state form becomes crucial. We must ensure the virtual state promotes equality and does not exacerbate existing discriminations or create new cleavages between citizens of Canada or among members of the global village.

\section{e-democracy vs. e-quality}

Although there are numerous active dialogues debating the possibility of direct democracy overtaking representative democracy, I am not going to visit these discussions here. Instead, I argue that electronic democracy does hold the potential to expand the democratic process in Canada. By an expansion of democracy I am suggesting that the current organization of state representation and federalism will remain intact; however it will be augmented by a growth of citizen input concerning political decisions. As a political tool, e-democracy would provide for open access to online discussions and consultations concerning policy initiatives. It would provide the impetus for electronic voting and online referendums, and may also lead to interactive and publicly broadcast parliamentary sessions. It has the ability to overcome the 'democratic deficit' a phenomenon associated with citizen frustration with government and the public mood of political apathy and cynicism (Alexander). However, to ensure that the virtual state expands state-society relations and promotes active citizenship, certain mechanisms must be put in place. First, the government must provide space for a contemporary commons, in which citizens may interact and pursue political goals collectively. Second, ensuring Interact access to Canadian citizens through public kiosks and state-sponsored training is imperative in upholding Canada's commitments to equality and counterbalancing the elitism associated with traditional politics. Third, initiatives must be taken to provide an enabling online environment, including appropriate portals/gateways, search engines, information sources, and an online settings that invites political participation from members of society. These measures would guarantee democratic resources to all Canadian 
citizens and ensure high levels of participation, open dialogue, equality, access to debate and the opportunity for community and/or ideological organization. Providing space for citizen involvement and civic engagement is imperative to the success of egovernment and thus the establishment of a public forum in which the state supplied opportunities for public chats, web boards for discussion, consultations and so forth would be highly advantageous.

Engaging citizens in political deliberation and strengthening civil participation through e-democracy entails a significant departure from the contemporary political practice of muted democracy. The primary prerequisite to an expansion of democracy is a system premised on inclusion and equality of opportunity. Women in Canadian society have never enjoyed the same democratic privileges as men. The democratic deficit experienced by women flows from the feminization of poverty, women's lower incomes, care giving responsibilities, overt and concealed sexism, threats of violence, time deficits, lack of educational opportunities, the overarching failure of the federal government to use gender-based analysis $(G B A)$ in the construction and dissemination of social policy, and the state's lack of support for women's organizations seeking equality. For some women the barriers to participation are further exacerbated by factors of race, ability, ethnicity, sexual orientation, geography, language and class. Women and many marginalized others are thus forced to engage in a form of muted democracy, in which they may vote, organize politically, and have limited interaction with a preordained government agency designed to deal with ‘women’s issues.' If Ottawa’s GOL project is to be successful, an analysis of the gendered dimensions of e-democracy must be explored prior to implementation. Thus the GOL project should take advice from Joyce Green who views gender as a staring point of analysis as opposed to an appended perspective. According to Green 'one doesn't establish the agenda and then insert the forgotten, excluded, or implicitly irrelevant, perspectives, and topics. One begins with them. ${ }^{6}$ Currently, the gender-neutral approach echoed throughout the policy design, implementation and consultations processes associated with the Canadian virtual state

\footnotetext{
${ }^{6}$ Personal conversation with Dr. Joyce Green.
} 
serves to reinforce a system of muted democracy and excludes any analysis focused on the impact of GOL on women's lived experiences. This exclusion is unacceptable and serves to reinforce the hegemonic paradigm of neoliberalism, a governing philosophy that promotes the equality fallacy. ${ }^{7}$ The equality fallacy suggests that women have achieved equality in Canadian society and thus gender-specific analysis or a focus on women-centered issues is no longer required. The pervasiveness of this conjecture has severed to delegitimize the women's movement and truncate support for feminist organizations. Neoliberalism, operating as an active ideological force, has labeled such movements as 'special interest groups' that do not represent the popular public consciousness. As Janine Brodie explains, the movement's designation as "a special interest group ... implies that its demands are not in the general interest” $(1995,20)$. Under this guise, women’s groups are viewed as not speaking for 'ordinary Canadians,' but as lobbying for rights that are in conflict with the individualist character of neoliberalism and the current configuration of citizenship.

In reality, women are anything but an interest group constituting the majority of the Canadian population. The federal government has made a number of commitments, both domestic and international, concerning women's inclusion in the decision-making process and ensuring GBA be used in policy design. Nationally, the

\footnotetext{
${ }^{7}$ Janie Brodie explains that the political landscape of Canada is rapidly changing due to the pressure on the state to conform to the new global mold. Under the rubric of neoliberalism the state in abandoning the Keynesian model and adopting an agenda premised on deregulation, economic competitiveness, efficiency and minimal state intervention. According to Brodie this reconfiguration of the Canadian polity will usher in new forms of patriarchal and capitalist control, while further entrenching old forms of domination. She further argues that these initiatives will disproportionally impact on women as the state downloads responsibility into the private sphere. However, Brodie cautions feminists against glorifying the post-war welfare state, as it was also characteristically patriarchal, racist and homophonic. She instead advocates the adoption of a new feminist lens in which the state is studied as a social construct reflecting various forms of systemic discrimination. She argues that citizenship rights are being reconceptualized to reflect the neoliberal agenda, in which citizens are expected to take care of themselves and those who fail to become self-sufficient are considered problematic and deviant. Brodie contends that the Canadian women's movement must be conscious of the new challenges facing them in the current era of globalization and neoliberalism in order to comprehend the various dynamics and layers of oppression they are currently being faced with. See: Janine Brodie, "Canadian Women, Changing State Forms, and Public Policy" in Women and Canadian Public Policy (Toronto: Harcourt Brace, 1995); Janine Brodie, "Meso-Discourses, State Forms and the Gendering of Liberal-Democratic Citizenship" in Citizenship Studies, vol.1, no.2 (1997), 223-241; Janine Brodie, Politics on the Margins: Restructuring and the Canadian Women's Movement (Ontario: Robarts Centre for Canadian Studies, 1995); and Janine Brodie, "Restructuring and the New Citizenship" in Rethinking Restructuring: Gender and Change in Canada, Isabella Bakker, ed. (Toronto: University of Toronto Press, 1996), 126-140.
} 
integration of a $G B A$ in the production of public policy will fundamentally enhance the ability of government organizations to deliver services and programs that address the realties of women's lives and allow for the articulation of various feminist strategies. Exploring the gendered aspects of e-government will provide policymakers with "the basis for designing sharp policy instruments in areas where they may be rather blunt” (Friesn, 27). The need for gendered analysis and an appropriate evaluation framework is paramount in addressing the challenges poised by ICTs. The federal government's commitment to GBA flow from the 1995 document Setting the Stage for the Next Century: The Federal Plan for Gender Equality. In this report the government makes a number of promises concerning the manner in which a gendered lens would be adopted in the production of all public policy. In addition, the government pledged to incorporate more women into the decision-making process. Setting the Stage describes gender-based analysis as "intrinsic to quality policy analysis" and defines gender based analysis as follows:

Gender analysis is based on the standpoint that policy cannot be separated from the social context and that social issues are an integral part of economic issues. Social impact analysis, including gender analysis, is not just an add-on, to be considered after costs and benefits have been assessed, but an integral part of good policy analysis (18).

According to the federal government, gendered analysis is necessary for accomplishing gender equality and one of the main priorities for action is the federal government's commitment to "ensuring that gender is widely understood and used as a fundamental variable" (Canada, 1995, 34). The state's commitments to GBA were designed to comply with Section 15(2) of Charter of Rights and Freedoms and fulfill international obligations to gender inclusion and gender mainstreaming. ${ }^{8}$ Globally the

\footnotetext{
${ }^{8}$ Gender mainstreaming is the overarching goal of $G B A$, with mainstreaming referring to that moment in time when policy-makers will instinctively include a gendered analysis in the production of policy and programs. Obligating government to pursue the objective of gender mainstreaming flows from the Charter and from Human Rights Legislation. The Charter provides the following equality guarantees in Sections 15 and 28:

15. (1) Every individual is equal before the and under the law and has the right to the equal protection and equal benefit of the law without discrimination based on race, national or ethnic origin, colour, religion, sex, age, or mental or physical disability.

(2) Subsection (1) does not preclude any law, program or activity that has as its object the amelioration of conditions of disadvantaged individuals or groups including those that are disadvantaged because of race, national or ethnic origin, colour, religion, sex, age, or mental or physical disability.

28. Notwithstanding anything in this Charter, the rights and freedoms referred to in it are guaranteed equally to male and female persons.

Human Rights Legislation provided the following equality guarantees:
} 
Canadian state's commitments to equality flow from: the 1981 Convention on the Elimination of All Forms of Discrimination Against Women, which the Canadian state ratified without reservation, and the 1985 Nairobi Forward-Looking Strategies for the Advancement of Women. The statement of goals outlined in these two agreements was developed during the United Nations Decade for Women and were intended to oblige governments to initiate legislation that would guarantee women's full and equal participation in all spheres of economic, social and political life (Stienstra and Roberts ). The federal government's failure to uphold its commitments to equality and GBA in the context of GOL is abhorrent; however, this is exactly the manner in which the government has conducted the implementation of GOL, bypassing women's interests, excluding GBA from the policy process, and circumventing the concerns of feminist organizations.

In Canada, e-government holds enormous potential for serving as a vehicle of women's empowerment and expanding democracy; however, if the state continues to follow its current trajectory, e-government will perpetuate a system of muted democracy that fails to promote equality and entrenches existing social inequities. The current propensities of the state to treat women's issues as peripheral to state programming is indicative of the neoliberal agenda and must be contested to ensure women's full and equal participation in the e-government project. The state's failure to provide the necessary resources to those feminist organizations that represent women, the government's meager attempt to gather input concerning the gendered dimensions of ICTs, and the lack of government initiatives to ensure equal

2. The purpose of this Act is to extend the laws in Canada to give effect, within the purview of matters coming within the legislative authority of Parliament, to the principle that all individuals should have an equal opportunity to make for themselves the lives that they are able and wish to have, consistent with their duties and obligations as members of society, without being hindered in or prevented from doing so by discriminatory practices based on race, national or ethnic origin, colour, religion, age, sex, sexual orientation, marital status, family status, disability or conviction for an offence for which a pardon has been granted.

PART I - PROSCRIBED DISCRIMINATION

Prohibited grounds of discrimination

3. (1) For all purposes of this Act, the prohibited grounds of discrimination are race, national or ethnic origin, colour, religion, age, sex, sexual orientation, marital status, family status, disability and conviction for which a pardon has been granted.

See: Constitution Act, 1982. Canadian Charter of Rights and Freedoms and Canadian Human Rights Commission, The Canadian Human Rights Act. R.S., 1985, c. H-6, s. 2; 1996, c. 14, s. 1. 
opportunity of access showcases the continuing discrimination against women and marginalized others by the state. Without serious reconsideration of the current GOL agenda the so-called digitalized extension of Canada's civic community will not lead to an expansion of social equality, but instead reinforce the conventional system of muted democracy.

\section{Portals or Pigeon Hole: Examining Women's Points of Access}

The federal government contends that the virtual state will benefit all Canadian citizens by ensuring faster access to information, greater inclusion in policy debates, improved service delivery, the convenience of online forums, and greater transparency and accountability of the governing process (GOL website). While ICTs certainly hold the potential to serve as democratic resources, expand citizenship and empower women, they also have the ability to perpetuate existing inequalities and create further societal cleavages. ${ }^{9}$ Communicating women's ICT goals and demands effectively has become eclipsed by certain state initiatives and is systemically being subsumed in the complex web of bureaucracy. Women's access to information, their inclusion in public deliberations, and an all-embracing agenda for e-franchisement is crucial to the project of GOL. As e-government increasingly becomes the machinery through which the state seeks to manage itself and it citizens, the intentionality of the design process must be interrogated. Although a number of political curators are generating online domains specifically designed to promote citizenship participation, women's categorical exclusion from the activities surrounding this project suggests an underlying ideology intrinsically laced with hegemonic assumptions associated with the equality fallacy.

\footnotetext{
${ }^{9}$ The power of the Internet to act as tool for democratic purposes is exemplified by the anti-MAI campaign. Ronald Deibert describes the prominence of the web in the success of this campaign. "[A]ctivists in the United States and Canada opposed to the 1988 Free Trade Agreement interacted with each other through faxes, telephone exchanges, letters, and formal conferences. Although these types of links were just as vital in the anti-MAI campaign, what the Internet did was to add a dense layer of daily interaction to these links, intensifying the bonds between disparate members and fomenting a sense of international commonality" (95). Ronald Deibert, "Civil Society Activism on the World Wide Web: The Case of the Anti-MAI Lobby” in Street Protest and Fantasy Parks:

Globalization, Culture, and the State, David R. Cameron and Janice Gross Stein, eds. (Vancouver/Toronto: UBC Press, 2002), 88-108.
} 
This sense of international communality and the establishment of borderless communities that cut across the continuum of time and space are imperative to the future success of the women's movement. Women's engagement in the Canadian government's GOL project is essential in ensuring that women are included in their local, national, and global communities. Internet-facilitated governance and the opportunities it may offer to connect women, marginalized constituencies, feminist organizations and progressive social movements must be carefully policed to guarantee an agenda predicated on justice and equality. Although the web has the potential to serve as a democratic resource that promotes an expanded process of citizenship, its current trajectory is deeply enmeshed in a vision of capitalist nirvana. Thus we cannot not simply focus on how to get women to participate in e-government but instead create a framework that delineates strategies for an inclusive and enabling online environment that invites participation from those members of society that have traditional been excluded. Women's equality must be protected both domestically and internationally, obliging the state to uphold its commitments to gender mainstreaming while simultaneously ensuring "global ambitions do not eclipse national initiatives in the name of global solidarity” (Tomlinson, 408).

The virtual women's movement serves as a useful working model to explore the manner in which online organizations are able to provide an enabling environment, provide public dialogue, organize on a global scale and work towards social, economic and political, justice. Cyber feminist groups reject any assumptions associated with how to get women to participate in such online activity as egovernment, which shifts the responsibility to women and instead focus on creating an inclusive and enabling online environment that invites participation from those members of society that have traditionally been excluded. These groups offer a gallery of diverse topics, forums in which to exchange ideas, and provide userfriendly resources that encourage participation. As Wendy Harcourt describes it, “women's groups are using the internet as a way to break down barriers, exclusions and silences” (150). Meshed together in this feminist cyber philosophy is the continual desire to provide kaleidoscopic views, educate actors and promote global solidarity. The virtual women's movement includes global women's organizations, 
national feminist associations, labour groups, ad hoc online communities of women, individuals and grassroots cyber activists. These cyber feminist activities are fundamental points of access to women's empowerment; however a lack of resources and the loss of funding have impaired their organizing ability and threaten to undermine this important online venue.

Outside of a feminist arena, discussions concerning women's points of access have predominately taken place on the global stage as opposed to within national spheres. While such organizations as UNIFEM promote women's inclusion in ICTs from a platform predicated on a human rights approach, other global institutions like the G8's Digital Opportunities Task Force (DOT force) and the World Bank espouse agendas for connectivity and inclusion that are premised on profitability. The DOT force's strategy incorporates a number of equalizing measures designed to bring developing countries into the folds of the information economy. The desire to exploit these untapped markets has lead to an international move towards advertising ICTs as the harbinger for global competition. Proponents of these global agendas often promote capitalist interests by appropriating libratory discourses to serve elitist ends. They package themselves as humanitarians that wish to champion equality principles to conceal their agenda of promoting women as an important consumer market for ICTs consumptions. While the World Bank and the DOT force are obviously far more concerned with economic development than social inequalities, the rhetoric being used to sell the neoliberal hegemony hijacks the language of inclusion and equality to promote the compulsory acceptance of the profitable ICTs sector. Take for example the DOT force's recommendation for ameliorating the digital divide.

[A] fundamental requirement for reducing the digital divide is for countries to give priority to the development of their communications infrastructure and to provide universal and affordable access to individuals and all geographic areas of their country. A pre-requisite for this is to put in place pro-competitive policies in the communications sector and a regulatory framework that will support such competition $(D O T, 8)$.

The primacy of private sector interests over human concerns is prominent throughout the DOT force's uncritical approach to ICTs and the top-down consultation processes they employ. The objective is not to create an agenda that guarantees equality or inclusion for all global citizens, but rather to solidify an international economy in 
which the sovereignty of local government is dictated by the vagaries of the marketplace. As Leslie Regan Shade’s analysis punctuates:

The role of the private sector is reinforced throughout the [G8 Okinawa] Charter and in the Genoa Plan of Action. Governments, however, are there to create the most conducive atmosphere for private-sector initiatives: an unregulated and thus "IT friendly" environment, the promotion of competitive and open markets, the protection of intellectual property rights, the cross-border facilitation of e-commerce, the continued liberalization of the telecom industry and related services through the promotion of a strong World Trade Organization, the protection of consumer trust through OECD guidelines and privacy protection, and international efforts in fighting cybercrime (6).

These enormous economic powers seek to trump social issues with economic priorities by pressuring local governments to conform to a global agenda. Despite the pretense of philanthropy, the programs espoused by these profit driven groups are unlikely to increase women's points of access or promote women's inclusion in the global information society.

The Canadian government's GOL project, its mission to close the digital divide, and the neoliberal thrust towards lean government all factor into the state's agenda for uniting citizens online. The Canadian government has traditionally been structured as a top-down or vertical institution, with clearly defined jurisdictions and geographically defined constituencies (Franklin). The advent of ICTs fundamentally reconfigured this organization of state and society as an increasing number of Canadians began to partake in constituencies based on identity, interests, culture or ideology. The horizontal movement of capital and information augmented this trend by situating money and knowledge at the pinnacle of modernization. The state's motivation to get online, although closely aligned with corporate interests, was also advanced by several other forces operating in tandem, including citizens' calls for greater accountable and transparency on the part of government, the desire to remedy the increasing apathy among civil communities and the growing popularity and power of the Internet (Lenihan). The Canadian government contends that they will be able to address all of these issues through a process of digital restructuring which will shift the state towards a horizontal organization based on seamless government. This restructuring phase affords women with an opportunity to contest the online arrangement of the state and to place pressure on the government to endorse its commitments to GBA and equality. Before this can occur, however, women's points 
of access to the governing process and e-government must be established and guaranteed.

For citizens seeking information online, the distinction between access and accessibility is a real issue. Even when citizens do have access to ICTs, searching for a specific piece of government information online is rarely a simple or straightforward exercise. Designing better public information online must start from the perspective of the end-users of government information and requires an assessment of their needs, capacity to find, digest and use relevant information. Enhancing the accessibility of online information can be achieved by: providing online information in terms of specific life events or policy issues; search engines; software for style checking and improving the intelligibility of government texts; multilingual translations of official documents; and provision of online glossaries (OCED, 1).

To date, the government has focused on a three-pronged programme to entice Canadian citizens to participate in online political activities. First, the state has adopted an online consultation process, which is intended to promote bottom-up citizen interaction in online forums. Ideally, online consultations will create opportunities for all citizens to enter into state dialogue and impact decision-making outcomes. Online consultations provide citizens with the chance to voice criticisms, provide input and simply comment on government activities. The process is developed by means of electronic polls and surveys, and through a state sponsored cyber suggestion box that addresses citizen email. Online engagement, in contrast is an interactive forum in which citizens may enter into active debate and dialogue on specific issues or policy initiatives. Online engagement includes collaboration between individuals, organizations, interest groups, citizens, bureaucrats, and/or political actors. Email lists, web forums, chat sessions, bulletin boards, and group applications all facilitate online engagement. Unfortunately, initiatives focused specifically on women through either process are nonexistent.

Not only have women thus far been excluded from the discussions surrounding e-government, the information necessary to empower women and provide women's organizations with the tools for advocacy has been poorly planned. State-sponsored portals allow citizens to navigate the quagmire of documents, online publications, policy briefs, press releases, and speeches contained on government websites. The government has organized portal access into information by topic and information for specific client groups. Currently, Ottawa provides portals for nine constituencies: youth, Aboriginal peoples, seniors, newcomers to Canada, Canadians living aboard, children, non-Canadians, individuals with disabilities, and Canadian 
business (FGW). Women have categorically been excluded from constituting a cluster and despite the Canadian government's recent attempt to better 'organize' the category of gender on the Canada website, information remains erratically dispersed throughout a complex web of state sponsored sites. This so-called organization of women's issues allows the state to argue that gender has been given consideration without explicitly recognizing that women constitute a political consistency with specific issues, challenges, and concerns. Denying the necessity of a women's portal reinforces the equality fallacy and signals a serious retreat from women's equality measures. The failure to provide a women's portal flows from research conducted by the Treasury Board Secretariat. This ‘validation research’ was carried out with a series of twenty focus groups in six centers. The report suggests that women are unconcerned about sexism, racism, and homophobia:

The dominant feeling among women respondents was that the inclusion of a separate women's cluster would only serve to marginalize women further. The clearly articulated expectation was that women-specific issues - be they maternity leave related or health-related information - should be addressed in the topic-based clusters:

- "Don't insult me."

- "When would this stop? Do we then have links by sexual orientation?"

Counterpoint. While they did not initially notice, or protest the absence of a women's cluster, two women respondents noted that, should the Government of Canada have special programs and services for women, then it would be helpful to find them aggregated on a single women's page. One of the women also noted that, in that case, there ought to be a cluster for visible minorities as well. However, she was challenged by other women in the group on the basis that a link for visible minorities would go against the spirit of inclusiveness of Canada and would, in fact, discriminate against invisible minorities. Male and female participants who were members of visible minority groups - agreed, and advocated against the inclusion of a visible minorities’ cluster (23).

These research findings are perplexing considering the global support for women's inclusion in the information society, the popularity of woman centered web sites, the sheer volume of academic research focused on women and marginalized others, and the government's commitments to equality. Furthermore, responses suggesting that access to information would further marginalize the already marginalized illustrates the internalization of the equality fallacy and further entrenches the individualistic formula espoused by neoliberalism.

The government's failure to provide women with appropriate points of access suggests that gender does not matter in the configuration of e-government and reiterates the fallacy of equality. ICTs, however, are not gender neutral and thus such 
differentiating elements as insufficient income, lack of resources, lack of education, single parent responsibilities, geographic isolation, sexism, racism, ablism, linguistic preference, and free time must all be factored into the state's agenda (Hafkin). If the state is truly committed to investing in the interest of the civic actor then the government must expand women's points of access to information and decisionmaking power. A sincere pledge to expanding democracy would necessarily begin by embracing those members of Canadian society that have historically been excluded.

\section{Cyber Sisters Seeking e-Solutions}

Locating a formula that empowers women online promises to be a formidable task. First, a new vision of citizenship must be established. Second, we must locate tools that maximize women's participation in civic dialogue. Third, women's inclusion and opportunities for public debate on topics associated with modernizing the Canadian government must be established. In this section of the paper I propose several recommendations designed to empower women and obligate the state to promote equality. I have purposely chosen to omit any discussions of a national charter that protects citizens' digital rights, as the government's failure to uphold its other commitments concerning gender suggests that a nation charter would be of little substantive value to e-quality. Instead I discuss several prospects concerning the manner in which the government should address the gendered dimensions of the virtual state and what measures should be established to promote e-quality.

The first step towards empowerment is providing women access to civil society and ensuring that women's organizations possess the necessary resources for advocacy, political action, and projects aimed at equality and inclusion. Second, it is essential to revolutionize the current decision-making process to guarantee women's participation in all spheres of political, economic and social life. Next, empowerment requires agency, and democracy requires equality of opportunity, thus measures must be taken to ameliorate the cleavages between the technological haves and have-nots. Finally, the project of the virtual state must not allow technical aspects to trump the human side of political organization. If certain technologies threaten to undermine democratic principles and the human side of participation, these tools should be 
deemed inappropriate for public affairs. Instead, state sponsored technologies should reflect a system premised on human rights, the rule of law, and social, economic and political justice.

There is a wealth of feminist literature that invokes the use of Cyborg imagery to describe women's metamorphosis from technical user to active, liberated agent. The Cyborg metaphor is used to symbolize the convergence of the technical with the organic and explore the merger between women's lives, online activism, participation, and education. ${ }^{10}$ The Cyborg metaphor is a powerful ideal for women's long-term engagement with ICTs; however, before we cross this libratory threshold, we must ensure that women are able to connect and participate in online activity. Thus the first several recommendations will focus on access and the next several will explore inclusion, privacy and social responsibly. Each one of these topics needs to be addressed by both policy-makers and political actors in order to promote equality and empower women online and off. To begin, an articulation of citizenship within the context of a digital, globalized information society will be established.

The first set of recommendations are concerned with ensuring women's full citizenship in the context of a virtual state. Women's access to information, the decision-making process, resources for technology and infrastructure, and participation in the GOL project is imperative for identifying and overcoming women's obstacles to online activity. Currently, women's interests are systematically being impaired by the state’s failure to uphold its international and domestic commitments to gender mainstreaming and its complete disregard for including women in those policy-making processes that dictate the agenda of e-government. Thus the following four recommendations are designed to amend the current agenda

\footnotetext{
${ }^{10}$ For a full discussion of the Cyborg metaphor see: Mia Consalvo, "From Razor Girls to Bionic Women: Extraordinary Cyborg Women in Popular Culture” in Women's Bodies, Women's Lives: Health, Well-Being and Body Image. Baukje Miedema, Janet M. Stoppard \& Vivienne Anderson, eds (Toronto: Sumach Press, 2000), 294-311; Donna Haraway, Simians, Cyborgs, and Women: The Reinvention of Nature (New York: Routledge, 1991).
} 
to include $G B A$, ensure that women's groups are invited to partake in consultations, and obligate the state to provide the necessary information and resources to assist women in the transition to the digitalized state.

Recommendation \#1 - The government should act immediately to create a women's portal that provides women-centered information, activities and educational tools

Recommendation \#2 - The government should act immediately to expand the number of public kiosks in safe locations where women will not be intimated, harassed, endangered or inconvenienced. These locations may include government agencies, libraries, YWCAs, women's centers, educational institutions, shopping malls, community centers and churches.

Recommendation \#3 - The government should continue to work towards universal connectivity so as to accommodate women living in rural and/or isolated locations.

Recommendation \#4 - The government should incrementally implement programs that would provide funding and the other necessary resources to those nonprofit organizations that wish to offer educational courses associated with ICTs.

The second set of recommendations is concerned with women's inclusion in the development and deployment of the virtual state. Historically, women's greatest gains have occurred when women stood together in solidarity and made specific demands on the state, with the Charter serving as the seminal example. These objectives have usually focused on creating an atmosphere of understanding and cooperation between different constituencies and interests. The heterogeneous nature of Canadian women suggests that women's membership in communities will be divided along a number of axes of identity. To determine how exactly women expect to be included and to what degree women's groups, feminist organizations, grassroots activists, academics, or individual women wish to partake will require some in-depth, bottom-up research. Thus the state must enter into participatory and collaborative partnership with those constituencies and/or constituents that wish to be heard. The following recommendations are intended to act as a springboard for this process. 
Recommendation \#1 - The government should act immediately to engage women's groups and feminist organizations in an in-depth consultation process concerning the gendered dimensions of the $G O L$ project.

Recommendation \#2 - The government should act immediately to facilitate a consultation process focused on protecting community needs and creating synergy between technological and social priorities.

Recommendation \#3 - The government must gather aggregate data and institute policy measures that identify critical areas of analysis and address cleavages in digital literacy and gendered utilizations.

Recommendation \#4 - The government must respond to the perpetually increasing privatization of digital real estate and provide a digital common in which all Canadians may engage in civic dialogue.

The third set of recommendations focuses on social responsibly and is premised on a human rights agenda. Enshrined in most national constitutions are guarantees of privacy that act to protect citizens from intrusive state practices and policies (Daves). As Janlori Goldman maintains “a collective and conscious decision must be made that the architecture of the Internet will be designed to advance individual privacy by facilitating individual control over personal information” (98). Privacy is a fundamental aspect of human rights and if that privacy is impaired by either the state or corporate interests it becomes questionable as to what degree citizens will engage in online activities. Another core element of women's human rights is protection from violence, including sexual violence. Thus Internet service providers must be encouraged to establish self-regulating mechanisms that protect women in the public spaces of the Internet. The following recommendations flow from these basic human rights requirements.

Recommendation \#1 - The government must work with women's organizations and anti-violence organizations to end online violence against women, including pornography.

Recommendation \#2 - The government must ensure online privacy.

Recommendation \#3 - A strong partnership with the state, private and public sectors, and women's organizations must be established to advance and support the strategies that emerge from the aforementioned gendered analysis of the virtual state. 
Recommendation \#4 - The government must act to end online hate literature including misogyny, anti-lesbian and gay material, racism, and other forms of bigotry.

The democratic implications of e-government have the potential to empower women, but they also have the power to impair women's status as citizens. ICTs will prove to be a valuable resource in addressing issues and concerns facing women and other marginalized constituencies only if the government fulfills its obligations and commitments to integrating a gendered analysis in the planning and implementation stages. Although ICTs alone do not promote equality, under the right conditions these technologies can serve to catalyze social, economic and political injustices and encourage women's empowerment. Without collaborative efforts, effective tools and a profound focus on the human side of the e-government equation "ICTs will remain a technological side-show, the applications and services will continue to be the playthings of the global elite, and the digital divide statistics will continue to be alarming” (Marcelle, 1).

\section{Conclusion}

On October 21, 2002, Paul Martin delivered a speech at Osgoode Hall where he contended that Canada was entering "the most exciting decade of our times. Driven by the twin forces of globalization and technological advance, Canada faces a series of opportunities and challenges the scope and nature of which we have rarely seen before” (Martin, 10). Mr. Martin’s statement crystallizes how the Canadian state views the process of digital restructuring - global trends shape domestic rules and technological advancements are compulsory for modernizing government. There exists a general consensus among political actors and the popular media that ICTs are a new panacea for reviving democracy and overcoming political disengagement. Virtual government however, is unlikely to remedy these problems if the status quo is left unchallenged. If the federal government is committed to expanding Canadian democracy there must be a concerted effort to guarantee that all projects associated with creating the virtual state and the ensuing maintenance of that online polity is based on equality and social justice and does not exclude or silence certain constituencies or members of civil society. 
Throughout this paper my aim has been to construct a feminist design of an online state and elicit a wider conversation concerning women's participation in this process. This vision of a virtual Canadian state would be grounded in a human rights approach that incorporates measures ensuring social, political, and economic justice. It would pursue gender equality and promote participation from all Canadian constituencies including those predicated on sexual orientation, race, ethnicity, ideology, ability, age, class, language, geography, labour affiliation, religious affiliation, and domestic responsibility. The vision would not impair the developing worlds' pursuits but instead extend support and solidarity through the promotion of equality across the global village. It would guarantee that all citizens had the right to communicate as they chose both online and off and that government decision-making reflect the civic voice. Women's participation in these evolving forums and activities is imperative for all members of Canadian society to ensure that e-democracy expands the political process and creates a state that is representative and accountable to all members of the Canadian community. As the digital restructuring process of government is still evolving there are considerable opportunities to contest those facets of the cyberstate that may mute women's voice online or impair their opportunity to partake in the potentially empowering resources the Internet offers. With the ascendancy of the digital state, e-governance, and e-democracy comes a number of challenges and a plethora of opportunities for women and marginalized others. Facing these challenges is not solely the charge of the women's movement and advocates of women's empowerment, but is indeed the responsibility of all Canadians committed to democratic citizenship and the expansion of the democratic state. A rigorous effort must be made by an aggregate of interests including the state, private interests, and third sector parties to ensure the GOL project and ensuing reorganization of governance will result in an expansion of democracy and promote a participatory model of citizenship based on justice and equality. 


\section{Works Cited}

Adams, Alison. "Feminist AI Projects and Cyberfutures” in Women, Science, and Technology. Mary Wyer, Mary Barbercheck, Donna Giesman, Hatice Örün Öztürk, and Marta Wayne, eds. New York: Routledge, 2001. Pp.332-355.

Akubue, Anthony, I. "Gender Disparity in Third World Technological, Social, and Economic Development" in The Journal of Technology Studies. Vol. XXVII, No.2. Summer/Fall 2001. Pp.64-73.

Alexander, Cynthia J. "Cents and Sensibility: The Emergence of e-government in Canada" in How Ottawa Spends 2000-2001: Past Imperfect, Future Tense, Leslie A. Pal, ed. Ontario: Oxford University Press, 2000. Pp.85-209.

Bakker, Isabella. Unpaid Work and Macroeconomics: New Discussions, New Tools for Action. Ottawa: Status of Women Canada, 1998. URL: <http://www.swc-cfc.gc.ca/pubs/0662636074/index_e.html>

Balsamo, Anne. Technologies of the Gendered Body: Reading Cyborg Women. Durham: Duke University, 1996.

Blumler, J.G. \& Coleman, S. Realising Democracy Online: A Civic Commons in Cyberspace. No.2. London: Citizens Online Research Publication, March 2001.

Brodie, Janine. "Canadian Women, Changing State Forms, and Public Policy" in Women and Canadian Public Policy. Toronto: Harcourt Brace, 1995. Pp.1-28.

- "Meso-Discourses, State Forms and the Gendering of Liberal-Democratic Citizenship” in Citizenship Studies. Vol.1. No.2. 1997. Pp.223-241.

. Politics on the Margins: Restructuring and the Canadian Women's Movement. Ontario: Fernwood Publishing, 1995.

. "Restructuring and the New Citizenship" in Rethinking Restructuring: Gender and Change in Canada. Isabella Bakker, ed. Toronto: University of Toronto Press, 1996. Pp.126-140.

. "Restructuring and the Politics of Marginalization" in Women and Political Representation in Canada. Manon Tremblay and Caroline Andrew, eds. Ottawa: University of Ottawa Press, 1998. Pp.19-37.

Consalvo, Mia. "From Razor Girls to Bionic Women: Extraordinary Cyborg Women in Popular Culture" in Women's Bodies, Women's Lives: Health, Well-Being and Body Image. Baukje Miedema, Janet M. Stoppard \& Vivienne Anderson, eds Toronto: Sumach Press, 2000. Pp. 294-311. 
Canada. Constitution Act, 1982. Canadian Charter of Rights and Freedoms. URL: <http://laws.justice.gc.ca/en/charter/>

- Setting the Stage for the Next Century: The Federal Plan for Gender Equality. Ottawa: Status of Women Canada, August 1995.

Canadian Human Rights Commission, The Canadian Human Rights Act. R.S., 1985, c. R.S., 1985, c. H-6 July, 1996.

URL: $<$ http://laws.justice.gc.ca/en/H-6/>

Crow, Barbara and Graham Longford. "Digital Restructuring: Gender, Class and Citizenship in the Information Society In Canada” in Citizenship Studies. Vol.6. No.4. 2000. Pp. 207-230.

Daves, Simon. "Spanners in the Works: How the Privacy Movement is Adapting to The Challenge of Big Brother" in Vision of Privacy: Policy Choices for the Digital Age. Colin J. Bennett and Rebecca Grant, eds. Toronto: University of Toronto Press, 1999. Pp.244-261

Day, Shelagh and Gwen Brodsky. Women and the Equality Deficit: The Impact of Restructuring Canada's Social Programs. Ottawa: Status on Women Canada, March 1998.

Deibert, Ronald. J. "Civil Society Activism on the World Wide Web: The Case of the Anti-MAI Lobby” in Street Protest and Fantasy Parks: Globalization, Culture, and the State. David R. Cameron and Janice Gross Stein, eds. Vancouver/Toronto: UBC Press, 2002. Pg. 88-108.

Digital Opportunity Task Force. Digital Opportunities for All: Meeting the Challenge. Report of the Digital Opportunity Task Force (DOT Force) including a proposal for a Genoa Plan of Action,11 May 2001.

Elmer-Dewitt, Philip. “Snuff Porn on the Net” in Time International. Vol.145. No.7. February 20, 1995 P.49.

Friesn, Jane. "Gender Equality Indicators and Gender-Based Analysis” in Gender Equality Indicators: Public Concerns and Public Polices. Health Canada, Human Resources Development Canada, Statistics Canada and Status of Women Canada. Proceeding of a Symposium held at Statistic Canada March 26.and 27, 1998. Ottawa: Status of Women Canada, 1999.

Franklin, Ursula. "Every Tool Shapes the Task: Communities and the Information Highway" in e-commerce vs. e-commons: Communication in the Public Interest. Marita Moll and Leslie Regan Shade, eds. Ottawa: Canadian Centre for Policy Alternatives, 2001. Pp155-164. 
Green, Joyce. "Decolonization and Recolonization in Canada" in Changing Canada: Political Economy As Transformative. Wallace Clement and Leah F. Vosko, eds. Montreal \& Kingston: McGill-Queen’s University Press, 2003. Pp.51-78.

. "Resistance is Possible” in Canadian Women's Studies. Vol.16. No.33. Summer 1996. Pp.111-116.

Goldman, Janlori. "Privacy and Individual Empowerment in the Interactive Age" in Vision of Privacy: Policy Choices for the Digital Age. Colin J. Bennett and Rebecca Grant, eds. Toronto: University of Toronto Press, 1999. Pp.97-115.

Government of Canada. Government On-Line and Canadians. Ottawa: January 2002.

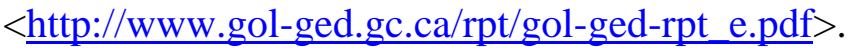

Hafkin, Nancy J. Are ICTs Gender Neutral? A Gender Analysis of Six Case Studies of Multi-Donor ICT Projects. UNINSTRAW Virtual Seminar Series on Gender and ICTs. Seminar One: Are ICTs Gender Neutral. 1-12 July, 2002.

Haraway, Donna. Simians, Cyborgs, and Women: The Reinvention of Nature. New York: Routledge, 1991.

Harcourt, Wendy. "World Wide Women and the Web” in Web Studies. David Gauntlett ed. New York Oxford Press. 2000. 150-158.

Herring, Susan, Kirk Job-Sluder, Rebecca Scheckler, and Sasha Barab. "Searching for Safety Online: Managing "Trolling” in a Feminist Forum" in The Information Society. Vol.18. No.5. 2002. Pp. 371 - 384.

Jenson Jane and Susan D. Phillips. "Regime Shift: New Citizenship Practices in Canada” in International Journal of Canadian Studies. Vol.14. Fall 1996. Pp.111-135.

Lenihan, Donald G. E-Government, Federalism and Democracy: The New Governance. Crossing Boundaries: Changing Government. Vol.9. Ottawa: Centre for Collaborative Government, 2002.

Levine, Peter. "Civic Renewal and the Commons of Cyberspace” in National Civic Review. Vol. 90, No3, Fall 2001. Pp.205-212.

Longford, Graham. Rethinking E-Government: Dilemmas of Public Service, Citizenship and Democracy in the Digital Age. Presentation to The Workshop on Public Sector Innovation. Sponsored by The Innovation Journal, The University of Ottawa, Carleton University, École national d'administration publique (Hull), and the City of Ottawa. University of Ottawa, February 9-10, 2002. URL: $<\underline{\text { http://www.innovation.cc/news/Innovation\%20Conference/longford.pdf }>}$ 
Marcelle, Gillian. From Conceptual Ambiguity to Transformation Incorporating Gender Equality and Women's Empowerment in the ICT Arena. United Nations Division for the Advancement of Women (DAW) Expert Group Meeting on "Information and communication technologies and their impact on and use as an instrument for the advancement and empowerment of women.” Seoul, Republic of Korea, 11 to 14 November 2002.

Martin, Paul. “The Democratic Deficit” in Policy Options. December 2002-January 2003. Pp.10-12.

McNutt, Kathleen. "Entering the Corridor of Hyper Technology: Women Jack In” in Canadian Dimensions. Vol.37. No3. May/June. Pp.34-36.

Menzies, Heather. "On Digital Public Space and the Real Tragedy of the Commons” in e-commerce vs. e-commons: Communication in the Public Interest, Marita Moll and Leslie Regan Shade, eds. Canadian Centre for Policy Alternatives: Ottawa, 2001. Pp.217-228.

. Whose Brave New World: The Information Highway and the New Economy. Toronto: Between the Lines, 1996.

Miller, Laura. "Women and Children First: Gender and Settling of the Electronic Frontier" in Resisting the Virtual Life: The Culture and Politics of Information, James Brook and Iain A. Boal eds. San Francisco: City Lights, 1995. Pp.49-57.

Organization for Economic Co-operation and Development. Engaging Citizens Online for Better Policy-Making. Policy Brief. United States, March 2003.

Reddick, Andrew, Christian Boucher and Manon Groseilliers. The Dual Digital Divide: The Information Highway in Canada. Ottawa: The Public Interest Advocacy Centre, July 2000. URL: < $\underline{\text { http://olt-bta.hrdc-drhc.gc.ca/resources/oltdualdivide_e.pdf> }}$

Regan Shade, Leslie. Heres Comes the DOT Force! The New Cavalry for Equity? Paper presented at the Panamerican and 2001 Bugs' conferences' in Montreal, April 24-27, 2002.

URL: <http://www.er.uqam.ca/nobel/gricis/actes/bogues/Shade.pdf>

Rheingold, Howard. The Virtual Community: Homesteading on the Electronic Frontier. Massachusetts: Addison-Wesley Publishing Company, 1993.

Sciadas, George. The Digital Divide in Canada. Ottawa: Statistics Canada, 2001.

Shea, Virginia. Netiquette. San Francisco: Albion Books, 1994. 
Stasiulis, Daiva. “Introduction: Reconfiguring Canadian Citizenship” in Citizenship Studies. Vol.6. No.4. 2002.

Statistics Canada. Overview: Access To and Use of Information Communication Technology. Ottawa: Minister of Industry, March 2001.

Stewart Millar, Melanie. Cracking the Gender Code: Who Rules the Wired World? Toronto: Second Story Press, 1998.

Stienstra, Deborah and Barbara Roberts. Strategies for the Year 2000: A Woman's Handbook. Halifax: Fernwood Publishing, 1995.

Sutton, Laurel A. "Cocktails and Thumbtacks in the Old West: What Would Emily Post Say?” in Wired_Women: Gender and New Realities in Cyberspace. Lynn Cherny and Elizabeth Reba Weise, eds. .Seattle: Seal Press, 1996. Pp.169187.

The Public Policy Forum. The Governance of Government On-Line: A Report on Research Conducted by the Public Policy Forum for the Chief Information Officer of the Treasury Board Secretariat. Canada, March 30, 2001.

Tomlinson, John. "Proximity Politics” in Information, Communication and Society, Vol. 3. No. 3. 2000. Pp. 402-414.

Treasury Board Secretariat. E-Cluster Blue Print: Validation Study. Ottawa: Phase 5 Research, 2002.

URL: <http://www.gol-ged.gc.ca/pub/validation/validation_e.pdf >

Wellman, Barry. “Computer Networks as Social Networks” in Science. Vol.293. September 2001. Pp.2031-2034.

United Nations Division for Public Economics and Public Administration American Society for Public Administration. Benchmarking E government: A Global Perspective. May, 2002.

URL: <http://www.unpan.org/e-government/Benchmarking\%20Egov\%202001.pdf>

\section{Websites}

Federal Government (FGW): < $\underline{\text { http://www.canada.gc.ca/> }}$

Government On-Line (GOL): <http://www.gol-ged.gc.ca/index_e.asp> 